\title{
Seiches Excited by the Atmospheric Disturbances within the Range of the Meteotsunami Periods nearby the Southern Part of the Sakhalin Island
}

\author{
D. P. Kovalev ${ }^{1}$, P. D. Kovalev ${ }^{1, *}$, M. O. Khuzeeva ${ }^{2}$ \\ ${ }^{1}$ Institute of Marine Geology and Geophysics, Far Eastern Branch of Russian Academy of Sciences, \\ Yuzhno-Sakhalinsk, Russian Federation \\ ${ }^{2}$ Sakhalin Hydrometeorological Service of Federal Service for Hydrometeorology \\ and Environmental Monitoring of Russia, Yuzhno-Sakhalinsk, Russian Federation \\ *kovalev_pd@outlook.com
}

Purpose. The aim of the paper is to study four synoptic situations, in which the seiches energy increase was observed in the coastal zone of the southern part of the Sakhalin Island, and to consider their possible meteorological origin.

Methods and Results. Records of the waves obtained in the Institute of Marine Geology and Geophysics in 2008 using both the instruments installed in eight points in the coastal zone of the southern part of the Sakhalin Island, and the synoptic maps provided by the Sakhalin Hydrometeorological Service Department, were used. For all the observation points, four synoptic situations characterized by increase of the seiches energy within the meteotsunami existence range were considered. It is shown that the amplitudes of the main part of the observed waves exceed the criterion equal to $4 x_{\text {mss. }}$. Therefore the events under consideration can be related to meteotsunami; at that, their energy is distributed almost all over the whole range of tsunami waves. When meteotsunami is absent, energy of the sea level oscillations in the range 4-120 min is reduced by an order. Since fluctuations are observed in the coastal zone possessing the resonant properties, arrival of meteotsunamis to these areas eventually results in exciting the seiches which are recorded. It is shown that in the coastal zone, cold fronts generate meteotsunamis, which, in their turn, give rise to seiches.

Conclusions. The conditions for generating sea waves by the atmospheric disturbances within the range of the tsunami periods $2-120$ minutes are described. It is found that movement of an extended cold front in the east-south direction leads to generation of the large-amplitude seiches in the region of the southern part of the Sakhalin Island, just where all the settlements are located. At a synoptic situation when two cold fronts are moving over the island, generation of high-amplitude seiches is possible in the places, near which a cold front is passing.

Keywords: meteotsunami, seiches, waves, cold front, atmospheric disturbances.

Acknowledgements: the work was carried out within the framework of the state task of the Institute of Marine Geology and Geophysics, FEB of RAS.

For citation: Kovalev, D.P., Kovalev, P.D. and Khuzeeva, M.O., 2020. Seishes Excited by the Atmospheric Disturbances within the Range of the Meteotsunami Periods nearby the Southern Part of the Sakhalin Island. Physical Oceanography, [e-journal] 27(4), pp. 402-414. doi:10.22449/1573-160X-2020-4-402-414

DOI: $10.22449 / 1573-160 X-2020-4-402-414$

(C) D. P. Kovalev, P. D. Kovalev, M. O. Khuzeeva, 2020

(C) Physical Oceanography, 2020

\section{Introduction}

The term "meteotsunami" has long been used to refer to sea waves that have periods close to the periods of tsunami waves of 2 minutes -2 hours, formed under the influence of earthquakes, landslides or volcanic eruptions. Unlike tsunamis, meteotsunami are generated over the open ocean by atmospheric pressure high- 
frequency modulations of gravitational waves, convective pressure surges or other types of atmospheric disturbances $[1,2]$.

However, the resonant energy transfer from the atmosphere to the sea alone is not enough for meteotsunami to reach destructive levels several meters high when approaching the shore. The coastal water areas - bays and harbors - should have high amplification factors [3,4]. Then meteotsunami, coming to the coastal zone with pronounced resonance properties, can give rise to seiches, the periods and amplitudes of which will depend on the parameters of a particular local topography.

A large number of papers published both abroad [1, 5-10] and in Russia [11-15] are devoted to the study of meteotsunami waves in the coastal water areas of the World Ocean different regions.

It can be seen that in the past two decades, the study of meteotsunami and the conditions for their generation has advanced very actively, and our understanding of the basic processes has improved significantly. However, according to the authors of [16], there are still enough open questions. Although it has been determined that the Proudman resonance plays an important role in the atmosphere - ocean energy transfer related to meteotsunami [17-20], it is still not clear how such resonance interactions or local bathymetry affect the amplification of meteotsunami [21].

In addition, since coastal water areas significantly differ in their resonance characteristics, the manifestation of meteotsunami, its amplitude and the possibility of generating seiches, that pose a danger to navigation, will also be different for each specific coastal water area. And this circumstance must be taken into account when carrying out works and surveys in the sea coastal zone.

Therefore, it was decided to continue the work on the meteotsunami study within the framework of the considered theme for Sakhalin region, despite the fact that we have already published several papers [14, 15], (especially considering the availability of extensive material of the sea level observations at different points of Sakhalin Island coast) and to analyze the generation of these waves, since it was found that during the passage of atmospheric disturbances, meteotsunami are not generated at all observation points.

The purpose of this work is to study four synoptic situations in which an increase in seiche energy was observed in the coastal zone of the southern half of Sakhalin Island, and consideration of their possible meteorological origin.

It should be pointed out that the recorded large amplitudes of level fluctuations during the movement of atmospheric disturbances over the coastal zone are, in fact, a consequence of seiches induced by meteotsunami. Probably, further it will be more correct to speak of oscillations anomalous in amplitude as seiches (as, for example, in [22]), although the term "meteotsunami" is often used to describe such oscillations.

\section{Observational data}

For the studies described in this paper, we used the wave records obtained in 2008 at the coastal points of Sakhalin Island (Fig. 1) and data of synoptic maps provided by Hydrometeorological Center of the Sakhalin UGMS (Federal State Budgetary Institution Sakhalin Administration for Hydrometeorology and Environmental Monitoring). The sea level fluctuations were recorded with onesecond discreteness using autonomous wave recorders. 


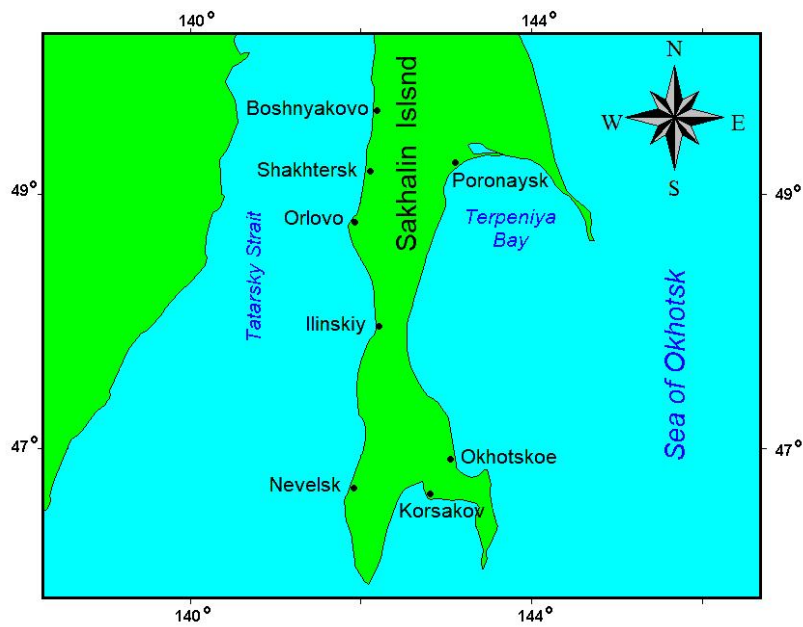

F i g. 1. Map of the southern part of Sakhalin Island and location of the settlements, near which the wave recorders were installed in 2008

Since the range of the meteotsunami wave periods is the same as that of the tsunami, the pre-calculated tide was subtracted from the observational data, after which the series were filtered by a band-pass filter with a 2-120 min window. In the filtered time series, four situations of significant rise in wave energy were observed in the considered range of periods: June 18, August 5, September 3 and 11. The time series for these time moments for 8 points are given in Fig. 2.

Initially, the analysis of waves within the range of meteotsunami periods was carried out for 10 points of the coast. However, some points (for example, Nevelsk and Gornozavodsk) are located close to each other and the wave regime in them differs slightly. Therefore, in the end, only 8 points were considered, but all 10 points were used for refinement. This approach allowed us to reduce the amount of figures in this paper.

As noted in [1], about 99\% of the energy of background fluctuations in the sea within the range of tsunami periods is associated with the atmospheric disturbances. Therefore, the anomalous level fluctuations that we found are presumably meteotsunami. However, not all sea level fluctuations can be attributed to meteotsunami. In [1], it was proposed to use the wave amplitude three or four times greater than the root mean square value $(r m s)$, determined by the equation below, as a criterion for the meteotsunami threshold

$$
x_{\mathrm{rms}}=\sqrt{\frac{1}{n}\left(x_{1}^{2}+x_{2}^{2}+\cdots+x_{n}^{2}\right)},
$$

where $x_{1}, x_{2}, \ldots, x_{n}$ are the amplitudes of the background waves, $n$ is their number.

$x_{\mathrm{rms}}$ values of the amplitudes of background waves in the range of meteotsunami periods for 8 observation points calculated from two-day time series during the events under consideration and one day before the onset of the September 3 event are given in Table. 1. It should be noted that the values of the background wave amplitudes were calculated before other events and showed a result close to that given in this table. 


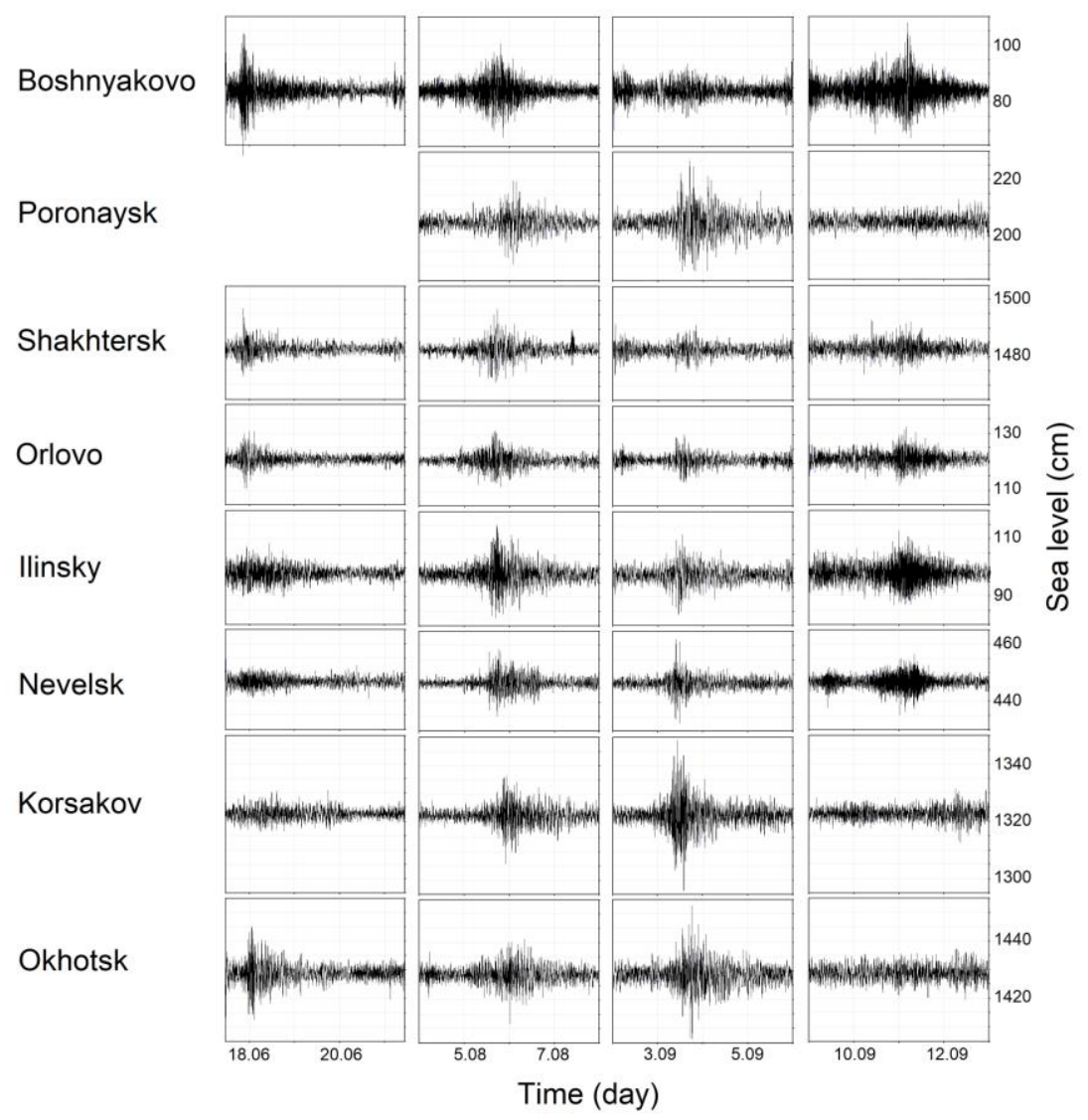

F i g. 2. Fragments of residual time series after filtering within the periods' range $2-120$ min for 8 observation points. The sea levels at the stations are represented relative to 0 of observation posts

It can be seen that the amplitudes of the main part of the observed waves exceed the criterion equal to $4 x_{\text {rms }}$, and therefore these events under consideration can be attributed to meteotsunami. At the same time, as the spectra of sea level fluctuations for the cases of meteotsunami arrival show (Fig. 3), the energy of the fluctuations is distributed practically over the entire range corresponding to the one of tsunami waves, apparently due to the fact that in the places where the measuring devices were installed, the resonance properties are manifested at several periods.

In the absence of meteotsunami, the energy of sea level fluctuations within 4-120 min range decreases by an order of magnitude, which can be seen from a comparison of the spectra for Orlovo (Fig. 3). In the short-period part of 2-4 min, the difference in the oscillation energy is smaller, which may be due to the presence of infragravity waves here. However, the peaks at the periods, which are presented in the spectra of coastal water areas for one observation point, do not change in the presence of an event. This indicates that they are natural oscillations. 
Values of the background amplitudes calculated from the two-day time series within the range of the meteorological tsunami periods based on the observations in 2008

\begin{tabular}{l|ccc|c|c}
\hline \multirow{2}{*}{$\begin{array}{c}\text { Observation } \\
\text { point }\end{array}$} & $\begin{array}{c}x_{\text {rms }}(\mathrm{cm}) \\
\text { (background) }\end{array}$ & \multicolumn{5}{|c}{$x_{\text {rms }}(\mathrm{cm})(\mathrm{events})$} \\
\cline { 2 - 6 } & 03.09 .2008 & 18.06 .2008 & 06.09 .2008 & 03.09 .2008 & 11.09 .2008 \\
\hline Boshnyakovo & 3.4 & 23.1 & 15.8 & 7.9 & 20.9 \\
\hline Poronaisk & 1.8 & & 14.7 & 19.7 & $\mathbf{5}$ \\
\hline Shakhtersk & 2.5 & 16.1 & 14.5 & 7.6 & 13.6 \\
\hline Orlovo & 2,1 & 11 & 10 & 7.7 & 12 \\
\hline Il'insky & 1.7 & 11.5 & 14.7 & 13.9 & 12.8 \\
\hline Nevelsk & 2.2 & $\mathbf{5 . 5}$ & 11.5 & 15.1 & 8.2 \\
\hline Korsakov & 2.9 & $\mathbf{7 . 6}$ & 13.8 & 26.3 & $\mathbf{8 . 7}$ \\
\hline Okhotskoe & 3.1 & 16.3 & $\mathbf{1 1 . 6}$ & 24.3 & $\mathbf{7}$ \\
\hline
\end{tabular}

$\mathrm{N}$ o t e. Values of the wave amplitudes that are less than the $4 \cdot x_{\mathrm{mms}}$ criterion are in bold; the date denotes beginning of the two-day interval of the time series for determining $x_{\mathrm{rms}}$.

At the same time, the periods of the peaks within the spectra for different observation points differ significantly. However, the general nature of the spectrum behavior for one observation point, as shown by the current spectra (for example, given for four points in Fig. 4), remains the same for a particular point. This shows that meteotsunami manifests itself locally in accordance with the resonance properties of specific water areas and their eigen oscillation periods, which is consistent with the conclusions made in other papers $[1,15]$.

It should also be noted that meteotsunami can reach dangerous amplitudes only if there is a local or regional topographic resonance in the coastal zone [1] and that external waves with high energy getting in the water area are not enough to generate large-amplitude seiches. It is necessary for the water area to have wellpronounced resonance properties, in particular, to have high quality factor ( $Q$ factor) [23]. 


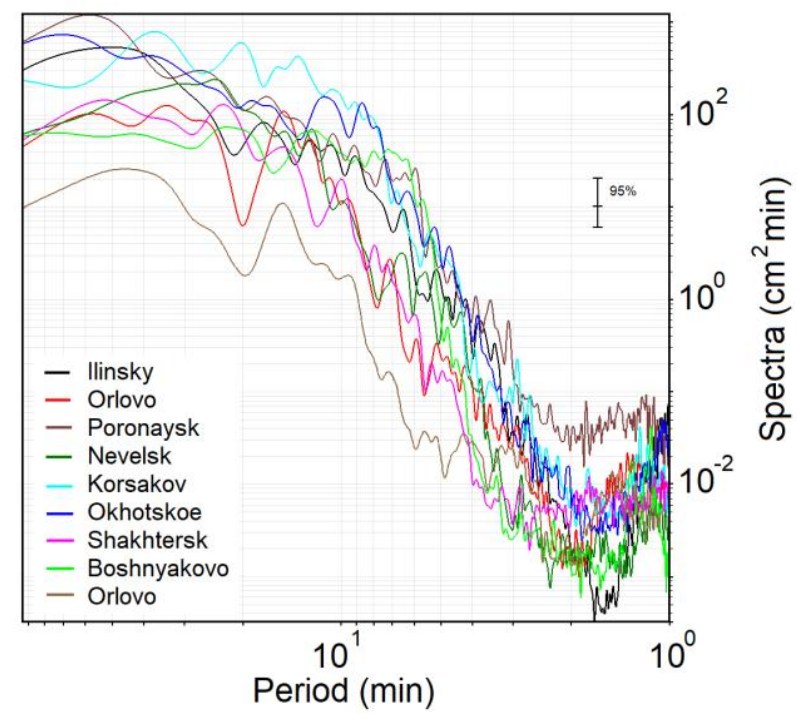

F i g. 3. Spectra of sea level fluctuations calculated using the daily time series for the periods of meteotsunami existence, September 3-4, 2008 and in the absence of an event (the lower spectrum for the point Orlovo)

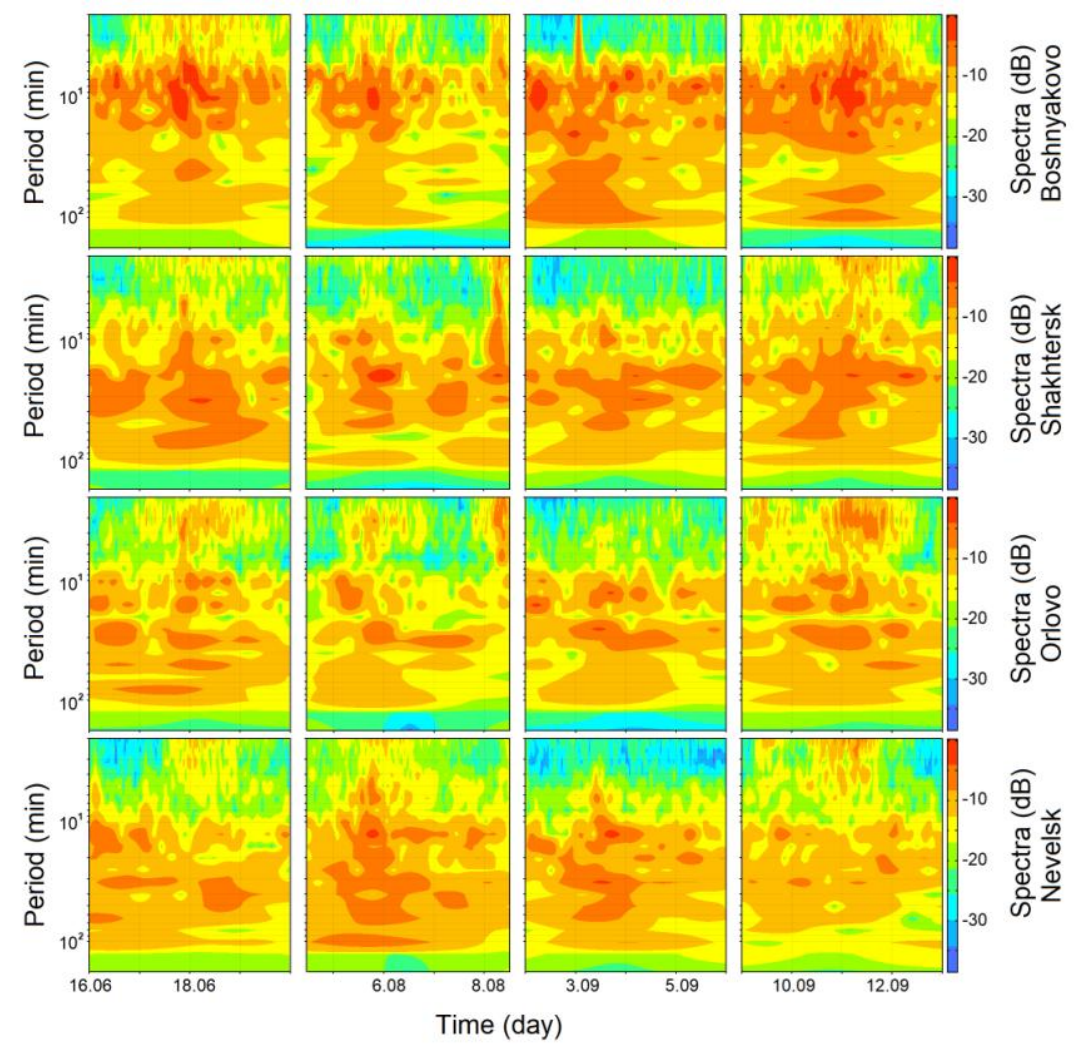

F i g. 4. Spectrograms of sea level oscillations for the meteotsunami events in four observation points 
The calculation of the resonance system quality factor of the water areas for periods of oscillations exceeding the $95 \%$ confidence interval in the spectra was carried out using the well-known equation [24]:

$$
Q=\omega_{0} / \Delta \omega
$$

where $\omega_{0}$ is a resonant frequency of a system (resonant maximum); $\Delta \omega$ is its width; $Q$ is its quality factor. In this case, the maximum width in the spectrum is defined as the frequency band, within which the oscillation energy decreases by half [24]. The calculation results are given in Table. 2.

Table 2

$Q$-factors of the resonant systems of the water areas adjacent to the observation points

for the periods of oscillations the energy of which exceeds $95 \%$ of the confidence interval in the spectra

\begin{tabular}{|c|c|c|}
\hline Observation point & Peak period, min & $Q$-factors \\
\hline \multirow{4}{*}{ Poronaisk } & 55.20 & 1.20 \\
\hline & 24.43 & 2.56 \\
\hline & 6.00 & 9.43 \\
\hline & 3.10 & 16.98 \\
\hline Il'insky & 9.13 & 8.44 \\
\hline \multirow{3}{*}{ Korsakov } & 36.18 & 1.19 \\
\hline & 4.58 & 11.18 \\
\hline & 2.92 & 11.16 \\
\hline \multirow{2}{*}{ Nevelsk } & 12.45 & 5.19 \\
\hline & 4.42 & 1.39 \\
\hline \multirow{2}{*}{ Orlovo } & 14.73 & 2.64 \\
\hline & 7.08 & 8.64 \\
\hline \multirow{4}{*}{ Boshnyakovo } & 1.13 & 33.99 \\
\hline & 1.30 & 15.78 \\
\hline & 12.22 & 3.55 \\
\hline & 21.73 & 1.89 \\
\hline \multirow{3}{*}{ Shakhtersk } & 10.00 & 5.77 \\
\hline & 14.28 & 3.89 \\
\hline & 22.70 & 2.19 \\
\hline \multirow{5}{*}{ Okhotskoe } & 2.02 & 13.31 \\
\hline & 3.83 & 16.55 \\
\hline & 4.67 & 12.37 \\
\hline & 7.82 & 6.74 \\
\hline & 6.32 & 7.02 \\
\hline
\end{tabular}

$\mathrm{N}$ o t e. Bold type marks out the seiche periods for the $Q$-factors exceeding 5 at which the amplitude is amplified by approximately 5.5 times. 
From Table 2 it can be seen that near all observation points there are resonant water areas with a quality factor of more than 5, at which a significant amplification of the incoming meteotsunami waves at resonance periods and the generation of seiches are possible. At the same time, a high quality factor is observed for oscillations with periods of up to several minutes, which will contribute to the manifestation of harbor oscillations, which causes a danger to anchored ships, during the meteotsunami arrival.

\section{Analysis of synoptic events}

From Fig. 2 it can be seen that at the movement of cyclones and cold fronts, an increase in wave energy over the southern half of Sakhalin Island is not observed at all points on the coast. Therefore, for the considered points in time, the synoptic maps provided by Hydrometeorological Center of the Sakhalin UGMS (Fig. 5) were used.

Synoptic events were analyzed in order to determine the generation source of anomalous seiches. The cyclones observed at the moments of meteotsunami manifestation were predominantly not a deep: for example, in the event on September 3, 2008, the movement velocity was $42.6-69.3 \mathrm{~km} / \mathrm{h}$, on August 6, 2008 , about $23.1-28.9 \mathrm{~km} / \mathrm{h}$ with pressure of about $1000 \mathrm{MPa}$. For the other two events, the cyclones were located at a distance from Sakhalin and therefore could hardly be the cause for the meteotsunami generation. Most likely, this cause was the cold fronts that usually accompany cyclones.

It should be noted that waves in the area of atmospheric fronts began to be studied relatively recently, and the experience of forecasting it under these conditions is still insufficient [22, 25-27]. The application of numerical methods in some specific conditions of wave formation is difficult to implement. Wind velocities during the passage of the fronts can reach $40 \mathrm{~m} / \mathrm{s}$, and sometimes even more [13]. Fast moving main cold fronts have especially strong winds.

An analysis of synoptic maps showed that several different events of the cold front movement are observed: one extended front, moving as if parallel to the island - from west to east (Fig. 5, c); one extended front, coming from the west, gradually unfolding over the island and further moving from north to south (Fig. 5, $b$ ); two separate fronts in the northern and southern parts of the island moving over the considered part of Sakhalin Island from north to south (Fig. 5, $a, d$ ).

For the synoptic event on June 18, 2008 (Fig. 5, a), the cold front movement velocity in the northern part of the island was about $16.7 \mathrm{~km} / \mathrm{h}$. In this case, the front contributes to the active generation of meteotsunami, which generates seiches in the coastal zone of Boshnyakovo with an amplitude 6.8 times higher than the $x_{\text {rms }}$ value for calm weather. The generation of seiches in the southern part of the island was affected by another cold front, which, moving eastward, moved southward at a velocity of about $9.3 \mathrm{~km} / \mathrm{h}$. At the same time, the maximum amplitudes of seiches were recorded in the area of Okhotskoye, although $x_{\mathrm{rms}}$ excess was only 5.3 times due to large amplitudes of background waves. Note that for the event under consideration, no closely passing cyclone centers were observed, i.e. active generation of seiches was provided by cold fronts only. 

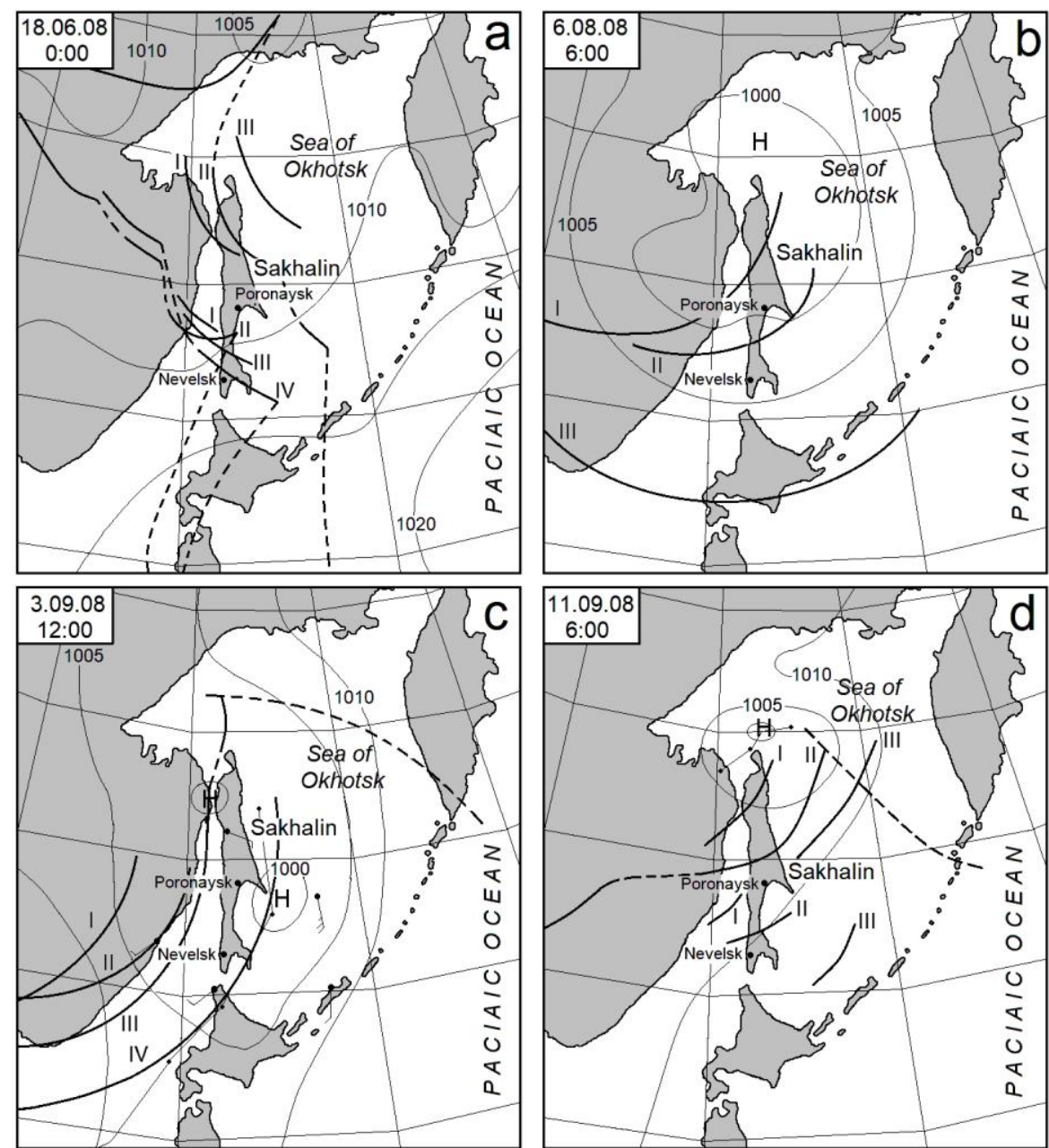

F i g. 5. Synoptic maps for four meteotsunami events. Positions of cold fronts for the maps $a$ ) I 17.06.08, 18:00; II - 18.06.08, 0:00; III - 18.06.08, 6:00; IV - 18.06.08, 12:00; b) I - 5.08.08, 18:00; II - 6.08.08, 6:00; III - 6.08.08, 18:00; c) I - 2.09.08, 18:00; II - 3.09.08, 6:00; III - 3.09.08, 12:00; IV - 3.09.08, 18:00; $d$ ) I - 11.09.08, 0:00; II - 11.09.08, 6:00; III - 11.09.08, 12:00. Solid bold line shows positions of the cold front; dotted line - positions of the warm front for the date on the map. Time $U T C+0$

In the event on August 6, 2008 (Fig. 5, b), one extended cold front moved from the northwest, turning in a southward direction; its velocity over the western coast of the southern part of the island reached $49.1 \mathrm{~km} / \mathrm{h}$. In this case, seiches of large amplitude were generated at all observation points, the maximum ones - in Il'yinsky and Poronaysk areas, where the excess was more than 8 times in comparison with $x_{\mathrm{rms}}$ level.

In the third event on September 3, 2008 (Fig. 5, c), not a deep cyclone moved along the eastern coast of Sakhalin Island from the Japan Sea at about $72.5 \mathrm{~km} / \mathrm{h}$ velocity. If it was the cause of the meteotsunami generation, and they, in turn, excitated seiches, then the time difference between the beginning of the amplification of seiches at the observation points Okhotskoe and Poronaysk, 
located on the eastern coast of the island at about $312 \mathrm{~km}$ distance, would be 4.3 hours. However, the real time difference between the arrival of meteotsunami and swell for these points is about 15 minutes. Therefore, we can conclude that in the event under consideration it is not the cyclone that is the cause of the anomalous waves.

In the event under consideration only one extended front moved in the EES direction, practically perpendicular to the western coast of Sakhalin, with a velocity of about $46.5 \mathrm{~km} / \mathrm{h}$ and completely covered the entire southern half of the island. Large-amplitude seiches were observed along the western coast from Il'yinsky and further southward, in the water areas near Korsakov and Okhotskoe; the seiche with the maximum amplitude, exceeding $x_{\text {rms }}$ by 10 times was observed in the vicinity of Poronaysk. The small amplitude of seiches in the area of Boshnyakovo and further to Orlovo is apparently connected with the fact that the cold front, when approaching the Tatar Strait, was located southward of these points and only when entering the Tatar Strait moved northward. Thus, the meteotsunami waves generated by it, which then induced seiches in the coastal part of the island from Orlovo to Boshnyakovo, did not swing to a large amplitude.

In the event on November 9, 2008 (Fig. 5, d), as in the first one, two fronts moved over the island, but approximately in the same southeastern direction, and not a deep cyclone was located over the northernmost part of the island the Schmidt Peninsula. Apparently, therefore it did not affect the formation of meteotsunami in the southern half of Sakhalin. At the same time, the northern front moved at about $20.4 \mathrm{~km} / \mathrm{h}$ velocity and caused the generation of large-amplitude seiches in Boshnyakovo, but bypassed Poronaysk, which can also be seen from the synoptic map. The southern front moved at about $29.7 \mathrm{~km} / \mathrm{h}$ velocity and contributed to the generation of seiches on the western coast of the island with the maximum amplitudes, which exceeded $x_{\text {rms }}$ by 5.7 times, near Orlovo but they were practically absent in the area of Korsakov and Okhotskoe. This circumstance may be explained by the fact that the front began to turn eastward over the southern tip of the island and the velocity of its movement southwards at that time slightly decreased.

\section{Conclusions}

The studies using the wave records carried out in 2008 at 8 coastal points in the southern half of Sakhalin Island and synoptic map data were described to identify anomalous sea level fluctuations generated by atmospheric disturbances.

The amplitudes of background waves calculated from two-day time series within the range of meteotsunami periods for 8 observation points showed that the amplitudes of most of the observed anomalous waves exceed the criterion equal to $4 x_{\mathrm{rms}}$, and therefore the events under consideration can be attributed to meteotsunami. At the same time, their energy is distributed practically over the entire range of tsunami waves, apparently due to the fact that the resonance properties of the water areas appear at several periods in the places where the devices are installed. In the absence of meteotsunami, the energy of sea level fluctuations within 4-120 min range decreases by an order of magnitude.

It is shown that near almost all observation points there are resonant water areas with a quality factor of more than 5, at which it is possible to amplify 
the incoming waves by meteotsunami at resonance periods and to generate seiches. It is noted that a high quality factor of resonant water areas is observed for oscillations with periods of several minutes, and therefore, during the arrival of meteotsunami, the generation of large-amplitude seiches with the periods of about three minutes, which means the manifestation of a harbor oscillations, which poses a danger to anchored ships, is possible.

It was determined that large-amplitude seiches are caused by meteotsunami, which are generated by cold fronts moving above the observation points. They can be located at a great distance from the cyclone, although it is believed that the fronts accompany the cyclones. At the same time, an extended cold front propagating in the EES direction leads to the generation of large-amplitude seiches in the water areas near all settlements in the southern half of Sakhalin Island.

In the presence of two different fronts moving over the island in the same direction from north to east or in opposite directions, the generation of largeamplitude seiches in resonant waters near which the cold front moves is possible.

\section{REFERENCES}

1. Monserrat, S., Vilibić, I. and Rabinovich, A.B., 2006. Meteotsunamis: Atmospherically Induced Destructive Ocean Waves in the Tsunami Frequency Band. Natural Hazards and Earth System Sciences, 6(6), pp. 1035-1051. doi:10.5194/nhess-6-1035-2006

2. Renault, L., Vizoso, G., Jansá, A., Wilkin, J. and Tintoré, J., 2011. Toward the Predictability of Meteotsunamis in the Balearic Sea Using Regional Nested Atmosphere and Ocean Models. Geophysical Research Letters, 38(10), L10601. https://doi.org/10.1029/2011GL047361

3. Rabinovich, A.B., 2018. Seiches and Harbour Oscillations. In: Y. C. Kim, ed., 2018. Handbook of Coastal and Ocean Engineering. Singapore: World Scientific Publ., pp. 243286. doi:10.1142/9789813204027_0011

4. Orlić, M., Belušić, D., Janeković, I. and Pasarić, M., 2010. Fresh Evidence Relating the Great Adriatic Surge of 21 June 1978 to Mesoscale Atmospheric Forcing. Journal of Geophysical Research: Oceans, 115(C6), C06011. https://doi.org/10.1029/2009JC005777

5. Hibiya, T. and Kajiura, K., 1982. Origin of the Abiki Phenomenon (a Kind of Seiche) in Nagasaki Bay. Journal of the Oceanographical Society of Japan, 38(3), pp. 172-182. https://doi.org/10.1007/BF02110288

6. Rabinovich, A.B. and Monserrat, S., 1996. Meteorological Tsunamis near the Balearic and Kuril Islands: Descriptive and Statistical Analysis. Natural Hazards, 13(1), pp. 55-90. doi:10.1007/BF00156506

7. Thomson, R.E., Rabinovich, A.B., Fine, I.V., Sinnott, D.C., McCarthy, A., Sutherland, N.A.S. and Neil, L.K., 2009. Meteorological Tsunamis on the Coasts of British Columbia and Washington. Physics and Chemistry of the Earth, Parts A/B/C, 34(17-18), pp. 971-988. doi:10.1016/j.pce.2009.10.003

8. Vilibic, I. and Sepic, J., 2009. Destructive Meteotsunamis Along the Eastern Adriatic Coast: Overview. Physics and Chemistry of the Earth, Parts A/B/C, 34 (17-18), pp. 904-917. doi:10.1016/j.pce.2009.08.004

9. Mehra, P., Prabhudesai, R.G., Joseph, A., Kumar, V., Agarvadekar, Y., Luis, R. and Viegas, B., 2012. A Study of Meteorologically and Seismically Induced Water Level and Water Temperature Oscillations in an Estuary located on the West Coast of India (Arabian Sea). Natural Hazards and Earth System Sciences, 12(5), pp. 1607-1620. https://doi.org/10.5194/nhess-12-1607-2012

10. Alfonso-Sosa, E., 2018. Meteotsunamis Revelan la Intensificación Rápida de los Huracanes. Ocean Physics Education, 25 p. Available at: https://www.researchgate.net/publication/328410352 [Accessed: 5 June 2020] (Preprint, in Spanish). 
11. Rzheplinsky, G.V., Matushevsky, G.V. and Yeshchenko, L.A., 1975. Unusual Swell Waves. Meteorologiya i Gidrologiya, 3, pp. 47-54 (in Russian).

12. Rabinovich, A.B., 1993. [Long Ocean Gravity Waves: Trapping, Resonance, and Leaking]. Saint Petersburg: Hydrometeoizdat, 325 p. (in Russian).

13. Nesterov, E.S., ed., 2013. [Mode, Diagnosis and Forecast of Wind Waves in the Seas and Oceans]. Moscow, 337 p. (in Russian)

14. Kovalev, D.P., Shevchenko, G.V. and Kovalev, P.D., 2015. [Propagation of Meteotsunami off the Seashore of Sakhalin Island]. In: Geodynamic Processes and Natural Hazards. Lessons of Neftegorsk: International scientific conference. Yuzhno-Sakhalinsk, 26-30 May 2015. Vladivostok: Dalnauka, vol. 1, pp. 312-316 (in Russian).

15. Kovalev, P.D., Shevchenko, G.V., Kovalev, D.P. and Shishkin, A.A., 2017. Meteotsunamis on Sakhalin and the South Kuriles. Vestnik of Far Eastern Branch of Russian Academy of Sciences, 1, pp. $79-87$ (in Russian).

16. Ličer, M., Mourre, B., Troupin, C., Krietemeyer, A., Jansá, A. and Tintoré, J., 2017. Numerical Study of Balearic Meteotsunami Generation and Propagation under Synthetic Gravity Wave Forcing. Ocean Modelling, 111, pp. 38-45. doi:10.1016/j.ocemod.2017.02.001

17. Rabinovich, A.B., Monserrat, S. and Fain, I.V., 1999. Numerical Modeling of Extreme Seiche Oscillations in the Region of the Balearic Islands. Oceanology, 39(1), pp. 12-19.

18. Marcos, M., Monserrat, S., Medina, R. and Vidal, C., 2003. Influence of the Atmospheric Wave Velocity in the Coastal Amplification of Meteotsunamis. In: A. C. Yalçiner, E. N. Pelinovsky, E. Okal and C. E. Synolakis, eds., 2003. Submarine Landslides and Tsunamis. NATO Science Series (Series IV: Earth and Environmental Sciences), vol. 21. Dordrecht: Springer, pp. 243-249. https://doi.org/10.1007/978-94-010-0205-9

19. Whitmore, P. and Knight, B., 2014. Meteotsunami Forecasting: Sensitivities Demonstrated by the 2008 Boothbay, Maine, Event. Natural Hazards, 74(1), pp. 11-23. doi:10.1007/s11069014-1056-0

20. Šepić, J., Vilibić, I. and Fine, I., 2015. Northern Adriatic Meteorological Tsunamis: Assessment of Their Potential through Ocean Modeling Experiments. Journal of Geophysical Research: Oceans, 120(4), pp. 2993-3010. https://doi.org/10.1002/2015JC010795

21. Vilibić, I., Šepić, J., Rabinovitch, A.B. and Monserrat, S., 2016. Modern Approaches in Meteotsunami Research and Early Warning. Frontiers in Marine Science, 3, Article 57. doi:10.3389/fmars.2016.00057

22. De Jong, M.P.C., Holthuijsen, L.H. and Battjes, J.A., 2003. Generation of Seiches by Cold Fronts over the Southern North Sea. Journal of Geophysical Research: Oceans, 108(C4), 3117. https://doi.org/10.1029/2002JC001422

23. Raichlen, F., 1966. Harbor Resonance. In: A. T. Ippen, ed., 1966. Estuary and Coastline Hydrodynamics. New York: McGraw-Hill Book Co., pp. 281-340.

24. Zernov, N.V. and Karpov, V.G., 1972. [The Theory of Radio Circuits]. Leningrad: Energiya, 816 p. (in Russian).

25. Ivanenkov, G.V., Matushevsky, G.V. and Rzheplinsky, G.V., 1977. The Resonance Generation of Surface Waves by Cold Atmospheric Fronts. Izvestiya of Academy of Sciences, USSR, Atmospheric and Oceanic Physics, 13(1), pp. 80-87 (in Russian).

26. Masterskih, M.A. and Sirotov, K.M., 1992. [On the Calculation of Wind Speed in Narrow Zones of Cold Atmospheric Fronts Over the Water Surface of Seas and Oceans]. Trudy Gidrometcentra USSR = Proceedings of the Hydrometeorological Research Center of the USSR, 324, pp. 130-134 (in Russian).

27. G. Persson, P.O., Hare, J.E., FAIRALL, C.W. and OTTO, W.D., 2005. Air-Sea Interaction Processes in Warm and Cold Sector of Extratropical Cyclonic Storms Observed During FASTEX. Quarterly Journal of the Royal Meteorological Society, 131(607), pp. 877-912. https://doi.org/10.1256/qj.03.181 
About the authors:

Dmitry P. Kovalev - Leading Research Associate, Head of Laboratory of Wave Dynamics and Coastal Currents, Institute of Marine Geology and Geophysics, Far Eastern Branch of Russian Academy of Sciences (1b Nauki str., Yuzhno-Sakhalinsk, 693022, Russian Federation), Dr. Sci. (Phys.-Math.), ORCID ID: 0000-0002-5184-2350, SCOPUS Author ID: 26032627700, ResearcherID: A-9300-2016, d.kovalev@imgg.ru

Petr D. Kovalev - Leading Research Associate, Institute of Marine Geology and Geophysics, Far Eastern Branch of Russian Academy of Sciences (1b Nauki str., Yuzhno-Sakhalinsk, 693022, Russian Federation), Dr. Sci. (Tech.), ORCID ID: 0000-0002-7509-4107, SCOPUS Author ID: 16429135400, ResearcherID: V-8662-2018, p.kovalev@imgg.ru

Marina O. Khuzeeva - Head of the Sea Hydrometeorology Department, Sakhalin Hydrometeorological Service of Federal Service of Russia for Hydrometeorology and Environmental Monitoring (78 Zapadnaya str., Yuzhno-Sakhalinsk, 693000, Russian Federation), marina-khuzeeva@rambler.ru

Contribution of the co-authors:

Dmitry P. Kovalev - scientific supervision of the research, data collection, processing and description of the study results, participation in the discussion of the paper materials, formulation of the conclusions, preparation of annotation text, critical analysis and revision of the text, preparation of the paper text

Peter D. Kovalev - analysis of the materials on the research theme, literature review in the research problem, processing and description of the study results, qualitative and quantitative analysis of the results, formulation of the conclusions, participation in the discussion of the paper materials, preparation of the paper text

Marina O. Khuzeeva - data collection, qualitative and quantitative analysis of the results, preparation of the initial version of the text

All the authors have read and approved the final manuscript.

The authors declare that they have no conflict of interest. 